\title{
Planning in the face of 'deep divisions': a view from Beirut, Lebanon
}

Article

Accepted Version

Mady, C. and Chettiparamb, A. (2017) Planning in the face of 'deep divisions': a view from Beirut, Lebanon. Planning Theory, 16 (3). pp. 296-317. ISSN 1741-3052 doi: https://doi.org/10.1177/1473095216639087 Available at https://centaur.reading.ac.uk/59517/

It is advisable to refer to the publisher's version if you intend to cite from the work. See Guidance on citing.

To link to this article DOI: http://dx.doi.org/10.1177/1473095216639087

Publisher: Sage

All outputs in CentAUR are protected by Intellectual Property Rights law, including copyright law. Copyright and IPR is retained by the creators or other copyright holders. Terms and conditions for use of this material are defined in the End User Agreement.

\section{www.reading.ac.uk/centaur}

\section{CentAUR}

Central Archive at the University of Reading

Reading's research outputs online 


\section{Introduction}

In this article, we engage with the literature on differences and conflict discussing principles on which planning might proceed in deeply divided societies. While planning has traditionally been regarded as a public sector top-down practice, increasingly planners have now started to also engage with bottomup initiatives which may take place beyond the boundaries of the planning profession, seeing a transformative potential in these through mechanisms of coproduction (Ostrom, 1996; Evans, 1996; Albrechts, 2012). Sometimes marginal, often small scale, these practices, are however argued to be important; while remaining attuned and embedded in local contexts, they can reveal the presence of normative ideals that potentially transcend the local. Studying such localised practices then means seeking ways in which normative ideas may be embedded in specific practices; therefore, seeking the abstraction of norms from the constructions of specificity enables the suggestion of principles that may transcend practices. Such an abstraction helps planners to recognise the transformative potential in projects even when these projects are not by themselves transformative in their current form. This study holds a view of the future that is not always determined by overwhelming structural forces of power, in the face of which action is inevitably destined to futility. Instead, this study embeds a faith in the potential for change that can be constructed through informed actions of multiple actors. In this sense the paper adopts a constructivist view of society, a view that allows for the construction of ideas, discourses and agendas that in turn frame and prompt action.

It is difficult to overstate the complexity of a project that aims to articulate a set of planning theories that speak to the realities of the global South-East as differentiated from the global North-West (Watson, 2009a, 2013; Yiftachel, 2006). This is for the simple reason that such a category is hugely diverse with situations on the ground spanning the entire spectrum of relative affluence to extreme poverty and relative harmony to 'deep differences' (Watson, 2006: 31). These divisions are also cast along a variety of cleavages each with its own particular dynamics, which in turn are compounded by numerous combinations of factors creating local uniqueness that defy easy generalisation. For instance, some 
factors highlighted by Watson (2009a) include rapidly increasing populations bringing with it new challenges for urban planning such as proliferation of slums and informal housing; infrastructure and other service deliveries being sourced from the community or other informal providers rather than the state; widening gaps between and within regions due to globalisation; rising centrality of informality as a 'dominant mode of behaviour' (p.2263) and under regulation leading to shady alliances, shifting definitions of legal/illegal and widespread prevalence of crime and violence. Some of these factors might also be found in the West and one could argue that this is becoming increasingly so, with the reality of the economic recession, deep inequality in wealth and the multi-cultural nature of contemporary Western cities. Conflict, deep difference, extreme poverty, and violence, then may no longer be the exclusive purview of the South-East. However, at the moment, extremes in adverse conditions may be more likely and more common, yet by no means exclusive, to the South-East. If this is accepted, then planning theorists need to be looking at theorisation for particular sets of conditions regardless of this being in the North, South, East or West. Experiences from the North- West or the South-East may then be drawn upon as long as the set of conditions make it relevant to the theorisation project undertaken. The level of theory one wishes to engage in will also influence the wider potential for applicability. So the applicability of a middle level theory may be more limited (geographically or contextually) than the applicability of a more generalised or abstract theory (see Chettiparamb, 2014 for more on levels of theory).

Within the context of the global South-East, the focus in this paper is on difference in the case of Lebanon, a country deeply divided by sectarian, political and social differences. We search for projects that may hold the potential for bridging such differences without eliminating the same in an idea of the universal citizen that denies difference (Fincher and Jacobs, 1998). This identification is a pre-condition for scaling up from bottom-up initiatives for affirmative action. The key question is then how we would recognise such a potential. This paper suggests a 'five-pathway framework' that is consolidated and derived from the planning and the political science literature that discuss conflict and contexts of deep difference. We do not suggest that the 'five pathway framework' present a set of coherent categories that together define an epistemological position in planning. Rather they are different approaches 
identified following a careful search in the planning and political science literature; a search that posed the question: 'What approaches have been identified as holding the promise for bridging deep differences?' This was posed to answer the wider epistemological question for planning that we were interested in: 'What principles must planners seek in projects in deeply divided societies to recognize potential for scaling up?' The 'five pathways' are therefore disparate pathways that are brought together loosely in a framework by virtue of their appearance as answers to the epistemological question posed earlier. This framework is thereafter used to identify transformative potentials in two projects of civic engagement operationalised by non-state actors, who are not urban planners.

The next section provides an overall contextual description of Lebanon highlighting its particularities. We then discuss the problem of planning in deeply divided contexts and identify five pathways that have the potential for transcending divisions inspired from literatures in planning and political science. The next section presents data from two bridging initiatives in Beirut, Lebanon, which are reviewed under the framework developed. The following section discusses the insights gained by applying the five pathways approach to the bridging practices, and finally we draw our conclusions.

\section{The Lebanese context}

Lebanon has an important geo-political location between the East and West, which has driven this small country to be embroiled in external conflicts in the region (Milton-Edwards, 2000). Modernisation took place in its early history following the fall of the Ottoman Empire (El Khazen, 2000) in the First World War. Lebanon was then under French mandate, until its constitution as the Republic of Lebanon in 1943, an officially secular state (Bollens, 2012). Due to its openness, modernisation, free-market economy and in particular banking services, pre-war Lebanon was referred to as the Switzerland of the East (Moubayed, 2007). The civil war, marked by a religious divide between Muslims and Christians, erupted in 1975 and its end was declared in 1989 with the Taif Agreement. Since then Lebanon has seen further conflict and violence, for instance, the political turmoil following the assassination of former Prime Minister Rafik Hariri in 2005, followed by the war with Israel in 2006, and further 
political and sectarian conflicts from 2007 to present. At present the repercussions of the Syrian conflict are affecting the political and security situation in Lebanon.

\section{Political factors}

The turbulent history of Lebanon has led to the collapse of the political system and a state that is weakened by consecutive wars and conflicts. Since its constitution, Lebanon, unlike its neighbours has tended to maintain its pluralism with its officially recognised 18 confessions (Bollens, 2012). This is reflected in the consociational form of government or specifically confessionalism, that characterises the state in Lebanon today (Jones, 2007). Consociationalism is a coalition government by a politically elite group, which represents different segments in society. Institutionally, it is characterised by a predetermined system of proportionality in public appointments, mutual vetoes and segmental authority (Milton-Edwards, 2000). When the different segments are divided along confessional lines, consociationalism becomes confessionalism ${ }^{1}$. In Lebanon key positions are assigned to represent the various sects: the President is always a Christian Maronite, the Prime minister, a Sunnite Muslim and the speaker of parliament, a Shiite Muslim (Nagle and Clancy, 2012)2.

Over the years, confessionalism together with a combination of internal and external factors has led to considerable instability and infighting in Lebanon resulting in the perception of a weak state. As Jones (2007: 104) states:

Today it [Lebanon] features, at least in the Western imagination, as the absolute epitome of destructive sectarian conflict, a zone without even the semblance of normal politics - violent, impossible and insoluble.

Alongside sectarianism, there is also a trend for leadership to stay in the family and with communal leaders, leading to the predominance of society over the state and the presence of feudal socialists in government (El Khazen, 2000). Jones (2007) reports that less than a quarter of members in the 2000

\footnotetext{
${ }^{1}$ Note that in this paper we use the term sectarianism and confessionalism interchangeably, to mean different sects within each of the two main religions: Christianity and Islam.

${ }^{2}$ This allocation of power was initially based on the 1932 census and proportion of sects (Genberg, 2002), with some adjustments done during the Taif Agreement and then in Doha in 2008 (Bollens, 2012).
} 
parliament were members of political parties, a situation that led the political scientist and MP Farid el Khazen to state that 'Lebanon does not have a party system' (Quoted in Jones, 2007: 109).

\section{Deep difference}

Sectarianism in Lebanon has been attributed to two histories: one internal and the other external (Larkin, 2012). Internally, sectarianism has been argued to be 'primordial', based on 'social bonds of cohesion found in tribal, kinship or communitarian solidarities' (Larkin, 2012: 42; Khalaf and Denoeux, 1998). Arguably, this aspect continues in the clientelism and patronage of politically active families in Lebanon (Larkin, 2012). Externally, it has been argued that the Ottoman Empire implanted sectarianism as a tool for ruling over groups in Lebanon (Larkin, 2012). This external perspective on sectarianism attempts to explain changes over time influenced by external politics as politico-sectarian coalitions vary according to prevailing political circumstances (Makdisi, 2008:559 in Larkin, 201: 43).

Different wars, linked to internal and external factors, whose objectives and actors have changed over time, have been fought on Lebanese territories (El Khazen, 2000). Unlike many conflict prone countries however, the wars in Lebanon were not primarily a protest against an authoritarian state, but were more a result of clashes between sectarian identities. The main ethnicity is Arab, although one part of the population manifests affinities with non-Arab countries mostly on the basis of religion and culture (Salibi, 2003). In addition to the two main religions and 18 sects, there is also the influx of refugees in the country, mainly Palestinian and now Iraqi and Syrian. This is a country where partly due to the weak state and partly due to strong divisions, allegiances and identities are to the sect or religion, or even to capital rather than the state. Consequently, civil society was from the outset powerful and active (El Kahzen, 2000).

The divided nature of society and the weakness of the state have led to sectarian communities, some of which operate as a state alternative by offering much needed services to their sectarian division within society (Cammett, 2011; Jones, 2007; Roy, 2009). These are large scale organizations wielding considerable clout. Our interest however is on transformative practices that may have the potential to 
bridge across sectarian divides. Hence, here we focus on particular activities of civil society that are not specifically defined in terms of religious or sectarian belongings.

Post-war Beirut is polarised into a predominantly Muslim West and Christian East along a demarcation line that splits the city (Khalaf, 2002). Significant numbers of internal population displacements have also taken place during the Lebanese war, resulting in settlements in and around Beirut (Khalaf, 2002). Events after 2005 have contributed to new divisions across sects rather than religions, mainly between Shiites and Sunnis. This has had spatial repercussions not only within some of Beirut's districts, but also within its suburbs (Bou Akar, 2012). The complexity of the post-war divides, and demographic changes related to sects and locations in and around Beirut simultaneously indicate highly homogeneous areas with one predominant sect alongside signs of mixing, especially along the former war-time demarcation line (Bollens, 2012: 162). While places of residence are relatively homogeneous, and some residents such as Hezbollah followers in the southern suburbs have a strong sense of belonging to their area (Deeb and Harb, 2013, Roy, 2009), work, leisure and commerce seem to include a mix of confessions (Bollens, 2012).

\section{Economic factors}

Lebanon is classified in the High HDI category and is ranked 72 from 187 countries (United Nations Development Programme, 2013). The overall level of economic development is relatively better than some other nations in the global South-East. However, Lebanese society has been described as having an almost depleted middle class, leaving an elite class of well-off Lebanese and an influx of less welloff diaspora, expats and refugees.

State policies in Lebanon have tended to support private property and private development in parallel with a liberal and free-market economy. This has encouraged significant investment in real estate, and one specific example is the reconstruction of the historical city centre that was planned and managed by the public-private real estate company Solidere, established under the decree 117 in 1991. Mechanisms of neo-liberal control of spaces and the development of shopping malls, high-end residential towers and waterfronts are also seen in Lebanon (Roy, 2009). 


\section{Planning in deeply divided and conflict prone societies}

One of the authors who have discussed planning in deeply divided societies is Vanessa Watson (2002, 2006, 2009a, 2013). Lebanon does not align completely with all the 'stubborn realities' highlighted by Watson (2013), in particular the nature of division, its historic genesis and its relationship with power and the economy as explained in the previous section. However, it reveals a unique context, characterised by 'deeply divided' fissures cast primarily along religious, political, sectarian, and social lines. As such it is relevant to the central concern for Watson: what does planning theory have to offer to planning practice in societies that are 'deeply divided'? Watson investigates the potential of procedural theories from an eclectic mix of communicative planning; political economy-based just city approaches; and the more post- modern approach of insurgency planning, which though informative in Western contexts, are argued to be of limited relevance to South-Eastern contexts (Watson, 2013). Explorations of theorisations in the literature on state-society synergies highlighting notions of complementarity; understandings of the emergence of new types of urbanisms and urban spaces, and the urban design literature that highlights design interventions in such contexts are argued, to be potentially valuable theoretical strands that could contribute towards the larger project of 'a view from the South' (Watson, 2013: 95; see also Watson 2002, 2009a). We extend this enquiry by recognising that Planning is also inherently a political activity (Albrechts, 2003), and in a similar vein to Watson (2013), we find insights and experiences that are valuable for planners in the political science literature. We draw on these to suggest that, in low scale bottom-up practices, planners might recognise one or more of five alternate pathways to bridge deep divisions. The routes and mechanisms for up-scaling these through myriad workings of the politics of power in institutions, actors and discourses are separate topics that are not addressed in this paper ${ }^{3}$.

\footnotetext{
${ }^{3}$ Routes to scaling up transformation or mechanisms through which planners can achieve change have been suggested by various authors such as by the production of 'sticky stories' where planners act as 'connectors' and 'policy entrepreneurs' (van der Stoep, 2014); through strategies and tactics operationalised through a dialectic of structure and agency (see strategic-relational approach suggested by Jessop, 2001, Chettiparamb, 2007; through models of change suggested by Woerkum, et.al. (2011); forms of planning such as insurgent planning (Sandercock, 2004), to name a few).
} 
The confessional form of government in Lebanon has been defended on the grounds that it is a mechanism for avoiding conflict and protecting the rights of distinct communities by affording all a share in power (Jones, 2007). Often the call against an anti-consensus view is informed by the rather bitter experience of aggravated violence and spiralling mistrust that result from an imposition of idealised democracy in a society that is internally torn. Consociational government then represents a view where differences in society are accepted as immutable and fundamental. The grounds are therefore pragmatic and non-normative given the 'deeply divided' nature of society. Proponents also argue that undesirable collective identities are likely to dissolve in the longer term after a period of consociational governance (O'Leary, 2005 cited in Nagle and Clancy, 2012). The rejection of the possibility of political consensus here echoes Watson's call in the planning discipline for a different form of planning in contexts characterised by 'deep differences', one that does not rely on consensus or a shared vision in societies (Watson, 2013).

Such forms of Government have also been critiqued primarily on the grounds that they institutionalise divisions in societies, thus preventing them from acquiring the skills and values necessary to transform into societies with shared sets of values (Nagle and Clancy, 2012). As Watson (2002) argues, valorisation of division is not always pragmatic and as such can lead to negative impacts. Further, institutionalisation of difference can also come at a cost in the long-term in that deep differences deepen even further. In this article therefore, as mentioned at the start, we adopt a constructivist view wherein the possibility of a bottom-up bridging of divisions exists.

A constructivist view to social differences sees the social consequence of ethnicity, race, sect, religion or by extension other difference as constructed in particular contexts by social agents through social processes. This is against the primordial view of identities as given and immutable across time and space. The primordial view thus urges the irreconcilability of difference by denying the possibility of recreation of identities (Bayar, 2009). A constructivist view on the other hand admits the possibility for a shift in the social antecedents and consequences of deep divisions. According to this view, even if 
current deep divisions in society may necessitate their accommodation, it is possible to imagine a polity that can develop or acquire values that are not necessarily confined to particular sects or religions. This may require the construction of additional identities that transcend more narrow identities, alongside current ones, and it is this possibility that lends itself to the promise of transformative change. In planning, such a constructivist view can be discerned in the consensus oriented communicative planning stream, which argues for the possibility of a shift in entrenched interests as a fundamental advantage (Innes, 2004; Forester, 2012). The central question to be posed then is: can a civil society be built based on values that may extend beyond one's own more narrowly defined individual, family, community, religious or sectarian identity?

We suggest five pathways that planning might work with such that, whilst the deeply divided nature of society is acknowledged, the cultivation of values that extend beyond a narrow identity is aimed. The paper is thus not focused so much on unravelling the mechanisms of how one or the other of the 'pathways' defined might work. The focus is more on the 'what'. In other words, what characteristics, might hold the potential for change? Even if the particular manifestation or combination of the five pathways would be context dependent, we believe that it is not restricted to deeply divided contexts in the global South-East, but will be applicable to all contexts where the deeply divided nature of society is a reality.

\section{Economic liberalism}

The argument for economic liberalism in planning is not new as expressed in the writings of many authors (Holcombe, 2013; Luo et al., 2013; Silva, 2011, for instance). In deeply divided societies, the argument is however slightly more nuanced. Economic liberalism when advanced as an ideology that can be deployed for bridging conflicts simply suggests that interest in economic prosperity and self advancement can be deployed by planners and others to erase fissures of difference by substituting identity politics with an interest in individual economic progress. As Montesquieu states:

Commerce cures destructive prejudices; and it is almost a general rule that wherever there are soft morals... there is commerce; and that wherever there is commerce, there are soft 
morals... One can say that the laws of commerce perfect the morals, for the same reason that these same laws destroy the morals. Commerce corrupts pure morals; that was why Plato complained of it; commerce polishes and softens barbarians' morals, as we are seeing every day. (Montesquieu quoted in Pangle, 2009: 22).

Commerce, it is argued, though a double edged sword, can potentially have a mediating effect in the face of extremist politics by promoting opportunities for self advancement through cooperation. Though at a larger scale, the EU is a classic example of the promotion of the rhetoric of regional cooperation for economic advancement intentionally mobilised and promoted with the intention of resolving conflicts amongst European nations (Gebhard and Galbreath, 2013). The political project subsequently was also a planning project.

Using the case of Northern Ireland, Nagle and Clancy (2012) however argue that identity based fissures once created, cannot easily be stemmed by economic liberalism alone. Further, in the absence of a strong state that can ensure redistribution, free market dynamics can exacerbate existing fissures by favouring those identities that are able to access the fruits of market based reforms. Chirot (2009) argues that economic disparity, independent of general levels of wealth, can fuel identity based mobilisation of hatred, especially when the lines of fissures in one mirrors the other. Reconciling divisions can then prove to be more difficult. A high general economic prosperity is then no guarantee for avoidance of conflict.

\section{Place based identities}

Place based identities may be formed at any scale: national, regional or local. Planning theorists have long argued for the power of place based initiatives - often local - to promote integration, consensus and thereby bridge differences (Healey, 1997; Stephenson, 2010 for instance). In a political project within deeply divided societies such place-based planning initiatives have added significance as they can be methods to counteract more entrenched factional identities. Examples of the promotion of such place based identities in conflict ridden contexts include the promotion of a regional Northern Ireland or Ulster identity to counteract the division in Northern Ireland (Nagle and Clancy, 2012). Care is of 
course needed to ensure that such place based id entities are not conceived in terms of particular group identities leading to a reinforcement of existing divisions. Efforts to develop such place based identities must therefore be wary of and remain proactive in managing the development of any dominant factional bias $^{4}$.

\section{Interest based Identities}

Intersectional analyses from feminist studies have highlighted the multiple identity positions that we occupy in our everyday life (Phoenix and Pattynama, 2006 for instance). Not all of these multiple identities necessarily constitute fissures leading to deep difference. Some of the multiple simultaneous identities might be defined by interests, for example, being a singer or an artist, while some may be defined by personal relationships such as being a mother or daughter. In this case it is possible that certain identities might allow for the bridging of more contentious divisional identities. For instance, in societies that are ethnically divided, language or religion might provide unifying identities. Similarly, interest based identities such as sports or a perceived common foe can provide a unifying identity. The challenge is to encourage or allow for such 'bridging identities' to surface as an organising force strong enough to allow for mobilisation, one which encapsulates transformative politics with the capacity to bridge across divides. Where present or enabled, such identities are worth exploring.

\section{Consensus oriented processes}

Consensus oriented practices place emphasis on the power of the 'better' argument to triumph when the parties to the argument actively work towards creating conditions of argumentation that are perceived to be fair to all interested. The aim usually is to allow for communication and negotiation based on a common understanding of fair values. Consensus oriented communicative planning theory advanced by Healey (1997), Innes (2004) and Forrester (2012) among others, are well known in planning theory.

\footnotetext{
${ }^{4}$ For case studies and a fuller discussion on the creation of place based identities in planning see for instance Hague and Jenkins (2005) or Neill (1999).
} 
It has been argued that consensus oriented processes can only work when there is agreement that the differences between communities will be relegated to a 'private' sphere while the public sphere appears as 'neutral' (Seligman, 2009). Also conditions for 'ideal communication', which necessarily require the suppression of power, have been argued to be incredibly difficult, if not impossible to create (Hillier, 2003). Accordingly, it has been argued that consensus oriented practice works only if there is a degree of homogeneity and consensus already in society and that therefore this is not a workable proposition for societies characterised by deep divisions (Watson, 2006).

However, a large part of the work by Innes, Forrester and Healey, to name few authors, are derived from practices that have worked on the ground, in situations characterised by conflict. It is true that much of the above work comes from settings characterised by generally shared secular values which may not necessarily exist in deeply divided societies at a particular time. However, discounting consensus oriented practices altogether as irrelevant in the 'real world' or to contexts of deep difference, in our view, would be to throw the baby out with the bath water for the possibility for the same must be acknowledged to even make a start towards transformative practice. Such transformative practice must aim not just at projects or initiatives, though this may well constitute initial steps, but must imagine the possibility of a society that has the capacity to transcend factional identities. The works of planning theorists in consensus oriented planning have provided a rich and diverse set of micro-practices that could be effective to progress towards such a vision. They have also shown us the impact of different variables (venue, timing, stakeholder choice and so on, which in turn are influenced by power) on a situation to facilitate or impede consensus. A discussion for planning in deeply divided societies must then necessarily also build on these insights.

\section{Institutionalisation}

Institutional approaches rely upon institutions to encourage and promote a system of accommodative behaviour (Alexander, 2005; Healey, 1999, 2006; Moroni, 2010). It is an approach that relies upon the transformation of structures of social life from the bottom-up or top-down. These institutional structures might endeavour to facilitate or stabilise accommodative and transformative behaviour even 
though they may coexist with 'uncivil' practices and institutions. Processes of institutionalisation however often place an additional call on resources and require engagement with formal structures, which in deeply divided societies are often non-responsive. The challenge is to find ways of building up credibility and momentum that allow for the institutionalisation of often fragile processes through resources and networks of alliances where none might have existed.

The above review of the planning and political science literature suggests that the following five pathways - economic liberalism; place based identities; interest based identities; consensus oriented processes and institutionalism - can open up potentials and opportunities for transformative action. The potential dangers and challenges for a project of bridging deep differences in each of these ways have also been highlighted. Given the conflicting interests and powers operating in these difficult contexts of deep divisions, it does not take much for a project to swing from one extreme to the other. Therefore, planners attempting to build up transformative potential from the bottom up, in deeply divided societies, need to be able to recognise both the potentials and drawbacks in the specificities of an initiative for corrective action. Such a recognition is arguably the first step in building up politics of engagement towards transformative change.

In the next section we introduce two bottom-up initiatives in Beirut. The five pathway framework is used her to and examine and analyse the cases for their potential for transformative change at a particular point of time

\section{The case studies}

This section gives a brief account of the methods used for the fieldwork conducted in 2007, introduces two case studies, and focuses on the five-pathways framework as manifested in both. This framework allows us to highlight the features of each case, which hold potentials for a transformative project.

The research used a case study approach for a rich portrayal of two market cases within municipal Beirut to elucidate, explain and promote understandings that are generalisable beyond the purview of the specific context studied (Yin, 1981; Flyvberg, 2006). The case studies have been chosen because they are instances of bottom-up citizen led initiatives that manage to span more entrenched 
sectarian/religious identities ${ }^{5}$. Methods used included interviews and observations. Interviews with about 50 visitors to each market, all five vendors in the flower market and 14 vendors in the farmers market were conducted. Vendors came from various parts of Lebanon (see Table 1). Visitors came from administrative Beirut, but also its Southern and North-Eastern suburbs, indicating mobility to the centre outside their everyday territories. As mentioned earlier, spatial distribution in Beirut is very much based on sects/religions and therefore in the absence of the possibility for obtaining direct data on sectarian/religious identities in the conflict ridden context of Beirut, the spatial distribution has been taken as indicative of social divisions. In both markets, respondents suggested that though buying and selling characterise these spaces, the markets' value goes beyond consumption; the markets provide opportunities for enjoying being in the city by watching others, hanging around, sitting idle, encountering others outside their daily social circles, meeting friends or practising other activities that they enjoy, and experiencing Beirut in a different manner.

The two markets are centrally located, and easily accessible from different locations that are not necessarily categorised as 'East' or West' Beirut. The markets are also significant in that they do not target the kind of high end clientele that real estate developers such as Solidere do. This was evident in the responses of vendors and visitors, who were happy to see a spontaneous, self-organised parking space in contrast to the designed and sophisticated Solidere environment in the central district.

Table 1. Locations from which vendors and visitors come to the two markets as per interviews in 2007.

\begin{tabular}{|c|c|c|c|c|}
\hline Coming from & Flower vendor & Flower visitor & Farmers' vendor & Farmers' visitor \\
\hline Beirut, East & 0 & 23 & 0 & 14 \\
\hline Beirut, West & 0 & 12 & 1 & 21 \\
\hline Beirut, Central & 0 & 1 & 0 & 5 \\
\hline Beirut, Southern suburbs & 0 & 2 & 0 & 2 \\
\hline Beirut, Northern and Eastern suburbs & 1 & 3 & 2 & 3 \\
\hline Mount Lebanon & 2 & 6 & 5 & 5 \\
\hline South Lebanon & 0 & 0 & 2 & 0 \\
\hline North Lebanon & 0 & 0 & 1 & 0 \\
\hline The Beqaa & 1 & 0 & 3 & 0 \\
\hline Total interviewed & 4 & 47 & 14 & 50 \\
\hline
\end{tabular}

\footnotetext{
${ }^{5}$ More formal public spaces provided by the state such as Horsh Beirut and the Corniche waterfront have therefore been exlcuded.
} 


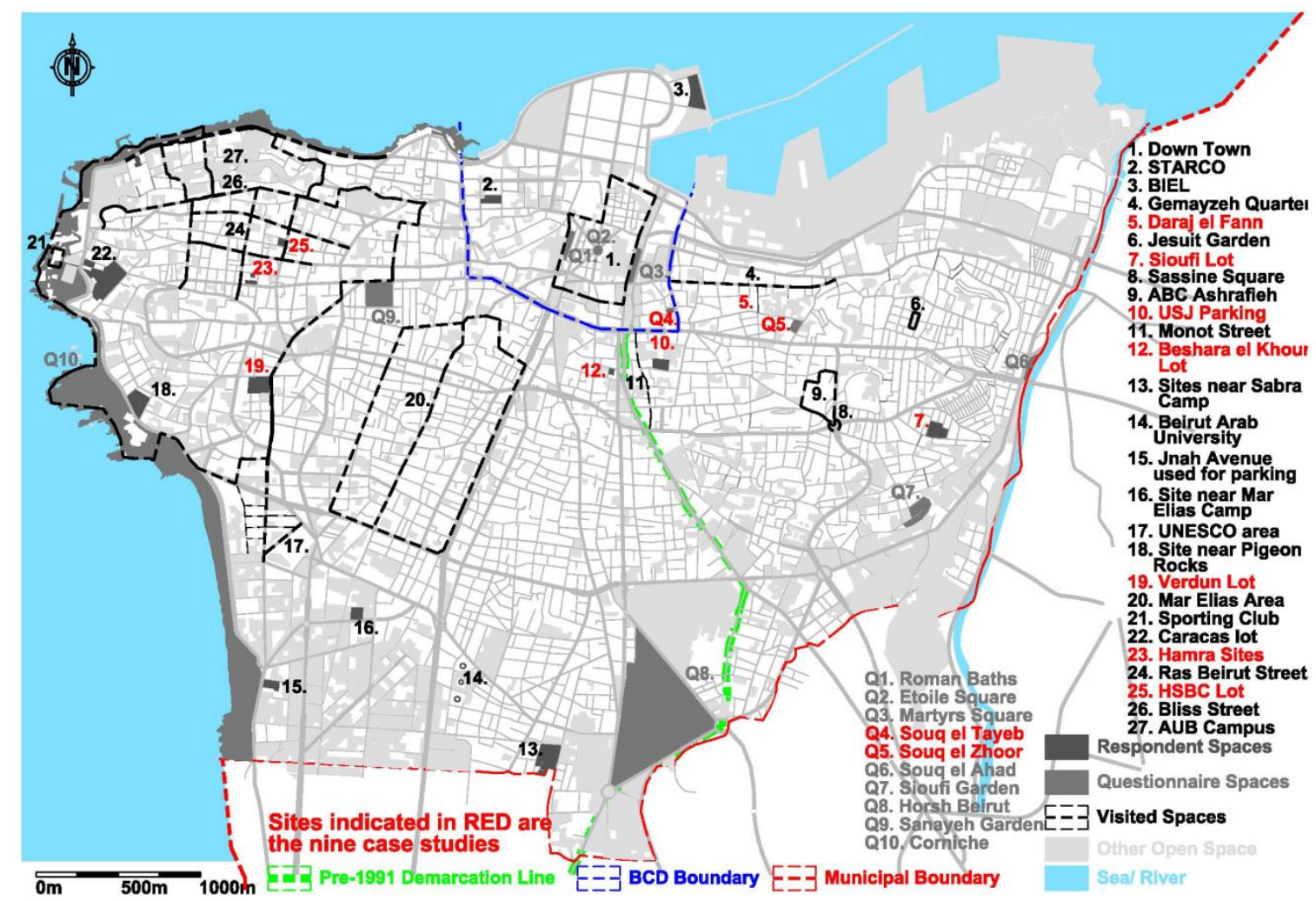

Figure 1. Map of municipal Beirut indicating temporary public spaces, the pre-1991 demarcation line and boundaries of the city centre.

The flower market: Souq el Zhoor. The flower market is a seasonal weekend market organised on vacant land that serves as a parking lot on weekdays near to the city centre. It started operating in 2000 . The market is organised by a syndicate of flower farmers who explicitly stress and promote a Lebanese identity by only showcasing flowers that are indigenous species planted and grown by Lebanese farmers in Lebanon. The political and national agenda of the organisers can be seen in the founding motives expressed below:

In the year 2000, after all the suffering from the war, they [120 Lebanese plant and flower farmers] formed a syndicate to try and disseminate their produce ... We are able to reach out to the Lebanese people and even educate them and encourage them to beautify their microenvironments ... We are trying to bring back the heritage of Beirut and the plants that were popular. There are plants that have always been planted here and are familiar to the people, to older generations and through memories, for example the jasmine ... We are not here for 
business ... above all there is interaction between vendor and client. There is a relation, a human relation and this is the beauty, the connection is the plant itself (Interview with the market organiser, 2007).

Given the sectarian polarisation, a notional group - the 'Lebanese people' - is the imagined client here. References to a heritage through a tradition of indigenous horticulture emphasise qualities of place over and above diverse or individualised cultural or social heritages. The 'Lebanese flower' or plant thus becomes a potential common identifier that aims to cut across socio-cultural divisions. Further, the market takes on a dissemination role in that it aims to educate the 'Lebanese' about their own place centred heritage whilst also encouraging further such localised dissemination. This occurs through episodic place based face to face interaction between vendor and visitor on the one hand and by evoking 'beauty' and 'micro-environments', in other words through the promotion of a place centred aesthetics and ecology on the other hand. The flower market thus becomes a place based political project that attempts to forge a new Lebanese identity through place centred instruments as in the case of Ireland discussed earlier.

Consumption is a daily social task involving the imperative to buy and sell products and services; but also lifestyle choices, ambiences, and ideas. Market places have therefore long been acknowledged as social places, places where social connections may be made and re-made, values reignited or discarded and the stranger encountered or avoided (Watson, 2009b). Both vendors and buyers are aware that the flower market is not just about consumption, but that it serves a larger social purpose.

So it is more than buy and sell, we have friends and relations with people (Interview with flower farmer 4, 2007)

Yes of course. You can build relations between people and understand the sociology of the markets. (Interview with visitor 2, 2007)

The flower markets intentionally pursue an inclusive agenda, making sure that flower farmers come from different parts of the country and are of different religions and sects. This variety is then not just ideologically consistent with the forging of a Lebanese identity, but also makes good business sense. 
The ideological underpinning however invokes a nostalgic past linked to a heritage of a different sort of social life and physical environment, thereby rekindling a sense of national pride which whilst contributing to business, also reinforces a Lebanese identity.

It reminds me of the village markets across Lebanon, and in rural areas (Interview with visitor 2, 2007)

Plants also remind me of an old house in Aleyh [in the Lebanese mountains] where I used to spend my summers! (Interview with visitor 40, 2007)

Of course, it is a place I think of because in Europe they do have these weekly markets all over, we do not have that, except for this place, it makes me feel proud! A place where all such flowers are exposed, am not sure if Arab countries have that at all; so when I see a blooming tree, I just feel happy! (Interview with visitor 40, 2007)

The flower market then effectively mobilises the social practice of consumption and transforms it as a constitutive practice for emphasising a Lebanese identity.

Flowers, gardens and flower markets are also an interest area. An interest in gardens and flowers per se is non-sectarian in its scope. Yet, its subject - flowers and plants - have the capacity to interest and mobilise subjects. These can be through diverse ways of engagement including livelihoods, hobbies and simple passive enjoyment. Such an affect can be seen through some of the responses from the user interviews below:

The meaning it has is that in Lebanon the farming of flowers is developing and this makes us happy and that this cultural phenomenon is growing. But since last year, we feel bad because the situation has such a negative impact on this development... it is a call for improving Lebanese production, to meet those who are attracted to values such as beauty and nature and also you would help those vendors (Interview with visitor 22, 2007)

I love flowers this is the attraction! (Interview with visitor 25, 2007) 
In Souq el Zhoor people go to gather, spend time and enjoy the flowers (Interview with visitor $8,2007)$

An interest based grouping by definition spans divides and brings people together into a common project as they come to be defined by the interest. Through ideological underpinnings, the flower market mobilises an interest based group into the political project of emphasising a national identity in the place of a sectarian identity.

The spatial location for the flower market was secured through a) the formation of a farmer's collective syndicate, which increased the bargaining power of farmers; b) the decision to locate in central Beirut, rather than the outskirts so as to enable easier access as well as occupy territory perceived as 'neutral'; c) the temporary re-use of a vacant car park lot in central Beirut which allowed for functioning with limited resources in a highly priced location and d) the securing of a permit from the municipality to hold the market thereby legitimising the endeavour (see Mady, 2013 for more on the location choice).

Beirut is a city with a shortage in public spaces (Mady, 2012). Following the war period, public spaces were annihilated due to the danger in being in an open urban space. After the war, and with the construction boom and real estate development, very little open space remains in the city. Also, the municipality only managed the few remaining public spaces, without creating a plan of providing new space to cater for the rising population (Mady, 2012). Under such conditions of shortage, finding and securing open spaces for conducting the flower markets is indeed a significant challenge. A further complication is presented by the polarised settlement geography of Beirut. As described earlier, the demarcation line cuts through Beirut effectively dividing the city into two sectarian parts. This means that the choice of location mattered, for the location carried with it connotations of sectarian allegiances, and central locations are the remaining few 'untinted' ones as explained earlier. In addition the bottomup nature of the initiative also meant limited access to resources and limited access to authority (unlike government driven projects) necessitating this temporary nature.

The farmers' market: Souq el Tayeb. The farmer's market shares many of the characteristics of the flower market described earlier. This market started in 2004 and was organised through a food 
producers' trading association. The market takes place on Saturdays, again on a vacant lot that is used as a parking facility on week days. As in the case of the flower market, the organisers explicitly promote a Lebanese identity, but this time through food and culinary culture. This principal goal is reflected in the following quotes:

It is not only commercial; it rather helps small producers to market their products, gives them a chance as well as encourages people to know about traditional Lebanese food (Interview with visitor 8,2007 )

No it is not commercial. It serves a social purpose: you cannot pinpoint differences between the people mainly it gathers people of different regions and religions, especially in a country like Lebanon; people with different mentalities, I don't know, something gathers people irrespective of their background/mentality. It might be as simple as an apple, you know? ... They do not have at all a common characteristic; there is no stereotype. (Interview with visitor 1, 2007)

We see here then a reference to 'food nationalism' through the promotion of Lebanese produce and culinary culture, which brings together individuals of various backgrounds. Besides the direct interaction of users with vendors in the market on Saturdays, promotion is also done by the organisation of other ancillary and complementary activities such as Lebanese culinary competitions on Sundays in different parts of Beirut but also Lebanon. Thus again the food market becomes a place centred instrument to emphasise a place centred heritage.

Alongside the emphasis on Lebanese produce, its many variations and Lebanese cooking, values that are linked with the materiality of the product such as 'freshness', 'organic', 'healthy', and 'tasty' are also invoked. These attract an interest based clientele who are aware of the food supply chain and are interested in making life-style choices that they believe to be healthy and non-exploitative.

For sure; it has a health value more than the commercial value, and I am very conscious about food chain and food supply (Interview with visitor 20, 2007) 
From the few I met there, they are THE people who like to cook they go and choose things to make a special meal, we go back to the essence of taste. ....you go there for small quantities, it is not a mass production (Interview with visitor 18, 2007)

It [the souq] signifies what I just said, green agriculture, value products and buying directly from producers ... beyond its commercial, first and foremost green agriculture, also awareness value and a way of life, how to grow your food without chemicals, encourage the producers and direct contact with consumers (Interview with visitor 49, 2007)

No, naturally it is commercial but has other values, the fact you come and buy natural products indicates it is not only commercial, it has an awareness value (Interview with visitor 46 2007)

The farmer's market also exploits its material base to actively promote a sense of public space, which, as mentioned earlier, is undersupplied in Beirut. The market is thus characterised by the provision of a gathering place, and a meeting point, alongside a diversification of activities.

Having a gathering place, which is completely lacking in a city like Beirut and is completely needed in a city that was shattered for such a long time. So playgrounds or parks are not enough; [one] should create a need, a necessity like buying vegetables and products of a certain quality [organic] not available elsewhere (Interview with market organiser, 2007).

The ambience of open space and people buying is interesting, rather than what is really displayed for selling; especially that we do not have open space activities in Lebanon anymore (they are not widespread) (Interview with visitor 2, 2007)

Sure, look at the public here! It is a mixture! What else do you want! If you go in a garden in Beirut, you will not find the same thing! You have a variety of goods and people hence come (Interview with visitor 10, 2007)

Personally yes, it is a meeting point; there is everything here and there is a mix of everything and everyone here! (Interview with visitor 23, 2007) 
The farmers' market is also a place of consumption, and caters to the mundane social activity of buying, selling and exchange. Price levels and accessibility are important attributes of markets, which can promote or restrict inclusivity and thus contribute or impede the inclusivity of ideological aims. While accessibility did not seem an issue, we got mixed responses on perceptions of price levels:

Open to everyone, you can just go there and buy nothing; it helps in experiencing Beirut in a different way (Interview with visitor 1, 2007)

Definitely, it is accessible to everybody, every passer-by could come in, it is not inhibiting, it is open to all - it is not like a gallery (Interview with visitor 49, 2007)

Yes it is very accessible, even in winter. Also, it is well fit in its context: everything is so rich and classy and this souq is in contrast to all (Interview with visitor 1, 2007)

There are no restrictions, at least not technical except for the price range; but again, one does not have to buy to be there (Interview with visitor 2, 2007)

Socially, it is important that it is free from sectarian and political issues. Also the food is healthy. People here are not after the money at all, even if prices are high, but the treatment of the vendors compensates as well as the healthy food ... Of course [it is public]. All types of people come here far from sectarianism and politics. All people are equal here (Interview with visitor 19,2007$)$

It suits all levels, and even if one does not have money, they can still find something to suit them. Also people could come just to change atmosphere and I love the place, the 'manzar' [view]' (Interview with visitor 40, 2007)

By embedding an ideological project in the daily practices of consumption, the farmer's market manages to engage in a political project that transcends the act of consumption evoking conviviality and promoting a sense of inclusiveness revolving around shared Lebanese identity beyond sectarianism. For at least some, it seemed to connect to what was termed 'a spirit of the village'. 
Personally, I love markets because this is the place where you find real people and real life. In markets, you learn about the life of the country... Because we always wanted to have the educational and awareness approach... It is not about this tomato and cucumber but about the "why"; then you would certainly buy those products ... it is a life choice (Interview with the organiser, 2007).

Yes, natural life brings people together; it gathers people of different religions and backgrounds and you do not feel any differences, political or religious (Interview with visitor 42, 2007)

Spaces such that are rare, rare spaces of conviviality, with the spirit of the village. Other places are commercial, political or 'social' so this is the only place of conviviality (Interview with visitor 7, 2007)

\section{Planning in conflict situations}

We suggested earlier that the central question for planning in societies defined by 'deep differences' might be: how can a civil society be forged when non-factional bonds of kinship, religion or language are not easily available, and when existing narratives and experiences are unhelpful? Given the increasing salience of bottom-up citizen initiatives in plugging societal needs and leading societal change in the face of a weak or ineffective government, our interest was to understand what characteristics a planner would need to recognise in such initiatives in order to effectively work towards transformative change. This paper does not address what planners can do in such contexts, but is concerned primarily with which characteristics hold the potential towards transformative action for bridging deep differences. The two case studies show that there exists, at the very least in Beirut, bottom-up initiatives that attempt to transcend prevailing sectarian divides cherishing and promoting a sense of conviviality. Such initiatives seem to draw upon a deliberate selection of cultural materialities of place, emphasising a unique geography and history. Through their concern for the future, their innately spatial character and engagement with the public, such projects are of interest to planners working in similar contexts. 
Jones (2007) suggests that in many Middle Eastern contexts, the idea of a nation-state is in tension with the grain of associational life as lived and facilitated by existing institutions. Social life in these contexts might be fostered and sustained through identities of family, kinship, sect, or language instead. Under such circumstances, Jones (2007) argues, the idea of political parties as common in the North-West can be viewed with suspicion for they can be seen as either or some of the following: 1) a vehicle for dictatorship; 2) a reinforcement of existing social cleavages; 3 ) an assembly of in-group elites and 4) an obstacle to the formation of a national consensus. As we have seen, Lebanon is governed by a confessional state, which though conceived originally as a temporary arrangement (Bollens, 2012) has never really transgressed into alternate forms.

Civil society is often seen in opposition to and sometimes a substitute for national and state institutions. Such a view arises particularly when civil society is seen as the answer to the failure of the state, i.e., when state institutions cannot or will not deliver to the needs of citizens (Chettiparamb, 2006). As Berman (2009) highlights, this view of Civil society has also been problematic, especially in situations of conflict when high levels of associational life need not necessarily mean high levels of tolerance or empathy towards the 'other'. This is often a consequence when associational life is patterned to reproduce axes of division more widely prevalent in society. Under such circumstances Chirot (2009) argues that the establishment of institutions normally regarded as fair such as free and fair elections for instance, could be problematic as this can be very threatening to the losers for it leads to a situation where the winner takes it all. The establishment of a genuinely transparent democracy can thus be counter-productive even if one is temporarily established. Chirot (2009) thus argues that creating a sustainable democracy in such contexts takes much more than holding elections or the moralising pressure from foreigners. It would necessitate the bottom-up creation of a national identity that can transcend factional identity first.

Ways of establishing a society that moves away from a narrow focus on factional identities then is a time consuming enterprise (now widely recognised and acknowledged with current experiences of Western engagement elsewhere). In our framework we suggested ways in which a narrow factionally defined identity might be transcended through five alternate routes. These involved the judicious use of 
commerce to 'soften' the hard edge of very narrow definitions of identity, the promotion of place based interests and identities (including a national identity) that can help transcend divisions, the nurturing of various interest based identities that can potentially bring various factions together; the promotion of a culture of negotiation and dialogue wherein differences can be sorted, and finally the creation and nurturing of institutions that can facilitate or stabilise top-down or bottom-up initiatives.

The case studies manifest instances of the working of the first three routes. Thus we find the use of commerce to bring together traders from all parts of the country from all sects in a syndicate or trading association to promote and sell their produce. Simultaneously, these markets were used to mobilise people to visit areas outside Beirut and all over the country. In a climate of increasing difficulty of sales due to imports, the general atmosphere of insecurity caused by the political instability and the incursion of high end shopping malls that cater for the wealthier, this can act as an incentive for reaching beyond sectarian identities.

Place based interests and identities have been encouraged by fusing the materiality of the interests with qualities of place. Thus in the flower market, indigenous flowers that aid and reinforce a Lebanese identity are marketed. Similarly in the farmer's market, Lebanese produce and culinary skills are celebrated. In terms of identity, such non-political activities give people hope of the co-presence of differences within national unity (Hanf, 1993). These initiatives bring various interest groups into the political project of nation building using the medium itself as the message.

An examination of the formal structures and resources that underpin the cases show the existence of a formalised institutional entity: the syndicate, and the trading association for which and on behalf of which, individuals self-organise. Top- down planning schemes and policies are not involved in these cases. The formation of such associations transcend narrow identities and they constitute the first step towards the realisation of the fourth and fifth routes that can have the potential to progress towards a more stable society that can learn to live with the 'other'. The organisational institutionalisation of the markets however does not match the spatial institutionalisation of the same. Spatially, the markets rely on temporarily activating rather mundane privately owned parking lots into vibrant public spaces where 
anyone can enter, enjoy, stay idle and meet the other serendipitously. The dearth of public spaces in Beirut might be one reason for this, but the shifting nature of the markets also helps in breaking spatially coded sectarian associations. Rather than planning for spaces of encounter, these initiatives illustrate transformative actions where 'sectarian interface' (Bollens, 2012: 198) becomes a positive step towards overcoming divides. These spaces allow for the 'flexibility and porosity' (Bollens, 2012: 240) in the city, features that could accommodate differences and integrate individuals through mundane activities of urban life. As Bollens (2012) argues, although encounters among sectarian groups exist in work places, commercial and institutional activities, initiatives - such as these markets - serve to widen interactions and expand social networks across sectarian communities. They to some extent therefore reinstate 'shared space' considered as a major war loss in Beirut (Bollens, 2012: 197).

The cases above then present specific instances of how the five pathways we identified theoretically might be visible in embedded practices. The pathways form a palette, but the particular mix and hue that can guide action in a particular case is situated and thus an empirical question. We find in these cases, initiatives where there is an attempt to bridge entrenched sectarian identities through the ideological active use of place, interests and materialities in practical projects. The nurturing and planning of such projects from the bottom-up or top-down is surely an enterprise that planners can identify with. Whilst it cannot be claimed that such initiatives will inevitably herald the end of violence and sectarianism, it can certainly be claimed, from the empirical evidence presented above, that they set the scene for ideas and attitudes that can accommodate the other. As Seligman (2009: 113) suggests the concept of civil society is when sociability is 'seen to rest in a shared capacity towards moral sentiments and natural sympathy among people seen to share in a public good'. The introduction, nurturing and eventual stabilisation of such public projects are endeavours that planners can promote.

\section{Conclusion}

In this paper we were interested in planning in deeply divided societies. We suggested that while planning is necessarily context dependent and there are a set of conditions that may more commonly be found in the global South-East rather than the global North-West, it is now a reality that these two 
geographies interlace more than ever. Under the circumstances, it would probably be more useful to talk about conditions in which planning of a certain sort might or might not work. This paper focused on the context of Lebanon - a country deeply divided by sectarian interests and known for its weak government. In these circumstances the central challenge for the planner is how a civil society based on values that exceed factional identities and interests can be built. There has been considerable interest in bottom-up initiatives lately, with planning thought (re)centring more towards civil society led initiatives. While the question of how planners might work with such initiatives is important, we argued that the question of what initiatives might hold promise in what types of change is equally important and must be answered apriori. Building upon the planning and political science literature, we suggested five separate characteristics that may need to be present individually or in combination in bottom-up initiatives that attempt to bridge deep differences. These involve the judicious use of market based initiatives, the active promotion of place based identities, the promotion of alternate interest based identities, the use of consensus-oriented practices and processes, and the effective use of institutions. The presence of these five pathways was demonstrated in two bottom-up initiatives in Beirut: a flower market and a farmer's market. Both cases show how an identity that is larger than a sectarian identity is advertised and promoted, by using strategies that encompass the five ways identified earlier. Whilst these 'bridging initiatives' are by themselves not the solution to the conflict, they certainly contribute to an agenda that seeks to transcend narrow sectarianism to encounter, share and appreciate a wider agenda. At the very least they provide conceptual and experiential resources useful in countering unhelpful stereo-typed presentations of the 'other'. The 'bridging enterprises' in the presented case studies build from materialities that are innately place-centred and people-centred thus evoking a geography and history that are wider than sectarian divisions. The judicious, but nevertheless ideological synthesis of enterprise, geography and history through specific materialities is of importance to planners and planning, in that it demonstrates the possibility for positive and meaningful action in 'deeply divided' societies.

\section{References}

Albrechts, L (2003) Reconstructing Decision-Making versus Politics. Planning Theory 2(3): 249-268. 
Albrechts, L (2012) Reframing strategic spatial planning by using a coproduction perspective. Planning Theory 12(1): 46-63.

Alexander E R (2005) Institutional transformation and planning: From institutionalisation theory to institutional design. Planning Theory 4(3): 209-223.

Bayar, M (2009) Reconsidering primordialism: an alternative approach to the study of ethnicity. Ethnic and Racial Studies 32(9): 1639-1657.

Berman S (2009) Re-Integrating the study of civil society and the state. In: Barany Z and Moser R G (eds) Is Democracy Exportable? Cambridge: Cambridge University Press, 37-56.

Bollens S A (2012) City and Soul in Divided Societies. Oxfordshire, New York: Routledge.

Bou Akar, H (2012) Contesting Beirut's Frontiers. City and Society24(2): 150-172.

Cammett M C (2011) Partisan activism and access to welfare in Lebanon. Studies in Comparative International Development 46 (1): 70-97.

Chettiparamb A (2006) Bottom-up planning and the future of planning education in India. Journal of Planning Education and Research 26 (2): 185-194.

Chettiparamb A (2014) Complexity theory and planning: Examining 'fractals' for organising policy domains in planning practice. Planning Theory 13(1): 5-25. 
Chettiparamb, A (2007) Steering Across Scales: Applying Strategic-Relational Approach To A Study Of Land Mobilisation For Road Widening In Kochi. Journal of International Development 19(3): 413427.

Chirot D (2009) Does democracy work in deeply divided societies? In: Barany Z and Moser R G (eds) Is Democracy Exportable? Cambridge: Cambridge University Press: 85-109.

Deeb, L and Harb, M (2013) Leisurely Islam: Negotiating Geography and Morality in Shi' ite South Beirut. Princeton University Press: Princeton, NJ and Oxford.

El Khazen F (2000) The Breakdown of the State in Lebanon, 1967-1976. Cambridge, Mass.: Harvard University Press.

Evans, P (1996) Government Action, Social Capital and Development: Reviewing the Evidence on Synergy. World Development 24 (6): 1119-1132.

Fincher, R and Jacobs, J M (1998) Cities of Difference, Guilford Press: New York.

Flyvberg B (2006) Five misunderstandings about case-study research. Qualitative Inquiry 12(2): 219245.

Forester J (2012) Learning to improve practice: Lessons from practice stories and practitioner's own discourse analysis (or why only the loons show up). Planning Theory and Practice 13(1): 11-26.

Genberg, D (2002) Borders and Boundaries in Post-War Beirut. In: Erdentug, A. and Colombijn F. (eds) (2002). Urban Ethnic Encounters: the Spatial Consequences. London: Routledge 81-96. 
Gebhard,C and Galbreath,D,J (2013) (eds) Cooperation or Conflict: Problematizing Organizational Overlap in Europe. Ashgate Publishing, Burlington.

Hague,C and Jenkins,P (2005) Place Identity, Participation and planning. Routledge, Abingdon.

Hanf, T (1993) Coexistence in Wartime Lebanon: Decline of a State and Rise of a Nation. London: Centre for Lebanese Studies in association with I. B. Tauris.

Healey P (1997) Collaborative Planning: Shaping Places in Fragmented Societies. Vancouver: UBC Press.

Healey P (1999) Institutionalist analysis, communicative planning and shaping places. Journal of Planning Education and Research 19(2): 111-121.

Healey P (2006) Transforming governance: Challenges of institutional adaptation and a new politics of space. European Planning Studies 14(3): 299-320.

Hillier J (2003) Agonizing over consensus: Why Habermasian ideals cannot be 'real'. Planning Theory 2(1): 37-59.

Holcombe R G (2013) Planning and the invisible hand: Allies or adversaries. Planning Theory 12(2): $199-210$.

Innes J (2004) Consensus building: clarification for the critics. Planning Theory 3(1): 5-20.

Jessop B (2001) Institutional (re)turns and the strategic-relational approach. Environment and Planning A 33(7): 1213-1235. 
Jones J (2007) Negotiating Change: The New Politics of the Middle East. London: I.B. Tauris.

Khalaf S, and Denoeux G (1998) Urban Networks and Political Conflict in Lebanon. In Shehadi N and Haffar Mills D Lebanon: a History of Conflict and Consensus. London: I. B. Tauris: 181-200.

Khalaf S (2002) Civil and Uncivil Violence in Lebanon: A History of Internationalization of Communal Conflict. New York: Columbia University Press.

Larkin C (2012) Memory and Conflict in Lebanon: Remembering and Forgetting the Past. Oxon, New York: Routledge.

Luo Z, Wang X, Zhang J and Hu Y (2013) Urban scaling-up and endogenous development promoted by continuous city marketing: A case study of Xuyi County, China. Planning Theory 12(4): 406-424.

Mady C (2012) A short story of Beirut's public spaces. AREA 120: Beirut (February): 36-37.

Mady C (2013) Social entrepreneurs and temporary public space supply: Beirut. Urban Design and Planning 166(6): 349-357.

Makdisi, U S (2008) Moving beyond orientalist fantasy, sectarian polemic and nationalist denial. International Journal of Middle East Studies 40(4): 559-560.

Milton-Edwards B (2000) Contemporary Politics in the Middle East. Cambridge: Polity Press.

Moroni S (2010) An evolutionary theory of institutions and a dynamic approach to reform. Planning Theory 9(4): 275-297. 
Moubayed S (2007) Lebanon douses a terrorist fire. Asia Times (5 September, 2007) http://www.atimes.com/atimes/Middle_East/II05Ak01.html (accessed 7 July 2014).

Nagle J and Clancy M C (2012) Constructing a Shared Public Identity in Ethno Nationally Divided Societies: Comparing Consociational and Transformationist Perspectives. Nations and Nationalism 18(1): 78-97.

Neill, W,J,V (1999) Whose city? Can a place vision for Belfast avoid the history of identity? European Planning Studies, 7(3), 269-281.

O’Leary B (2005) Debating consociational politics: Normative and explanatory arguments. In: Noel, S Jr (ed). From Power Sharing to Democracy: Post-Conflict Institutions in Ethnically Divided Societies. Montreal: McGill-Queen's Press, 3-43.

Ostrom, E (1996) Crossing the Great Divide: Coproduction, Synergy and Development. World Development 24 (6): 1073-1087.

Pangle T L (2009) The morality of exporting democracy: A historical-philosophical perspective. In: Barany Z and Moser R G (eds) Is Democracy Exportable? Cambridge: Cambridge University Press, $15-34$

Phoenix A and Pattynama P (2006) Intersectionality. European Journal of Women's Studies 13(3): 187192.

Roy A (2009) Civic governmentality: The politics of inclusion in Beirut and Mumbai. Antipode 41(1): $159-179$ 
Salibi K (2003) A House of Many Mansions: The History of Lebanon Reconsidered. London, New York: I. B. Tauris.

Sandercock, L (2004) The death of radical planning: Radical praxis for a postmodern age. In: Miles M, Hall T and Borden I (eds) The City Cultures Reader. New York and London: Routledge, 423-439.

Seligman A B (2009) Democracy, civil Society, and the problem of tolerance. In: Barany Z and Moser R G (eds) Is Democracy Exportable? Cambridge: Cambridge University Press, 110-128.

Silva E R (2011) Deliberate improvisation: Planning highway franchises in Santiago, Chile. Planning Theory 10(1): 35-52.

Stephenson J (2010) People and Place. Planning Theory and Practice 11(1): 9-21.

United Nations Development Programme (2013) Lebanon: HDI Changes and Rank Values in the 2013 Human development Report. arabstates.undp.org/content/dam/rbas/img/docs/Lebanon.docx_(accessed 1 August 2014).

Van der Stoep, H (2014) Stories becoming sticky: How civic initiatives strive for connection to governmental spatial planning agendas. $\mathrm{PhD}$ thesis, Wageningen University: Netherlands.

Watson S (2009b) The magic of the marketplace: sociality in a neglected public space. Urban Studies 46(8): 1577-1591.

Watson V (2002) The Usefulness of normative planning theories in the context of Sub-Saharan Africa. Planning Theory 1(1): 27-52. 
Watson V (2006) Deep difference, diversity, planning and ethics. Planning Theory 5(1): 31-50.

Watson V (2009a) Seeing from the South: Refocusing urban planning on the globe's central urban issues. Urban Studies 46(11): 2259-2275.

Watson V (2013) Planning and the 'stubborn realities' of global south-east cities: Some emerging ideas. Planning Theory 12(1): 81-100.

Woerkum, van C, Aarts, N and Herzele, van A (2011) Changed planning for planned and unplanned change. Planning Theory 10(2): 144-160.

World Bank (2014) Poverty headcount ratio at national poverty line (\% of population) http://data.worldbank.org/indicator/SI.POV.NAHC/countries/LB?display=graph (accessed 1 August 2014).

Yiftachel O (2006) Essay: Re-engaging planning theory? Towards 'South-Eastern' perspectives. Planning Theory 5(3): 211-222.

Yin R K (1981) The case study crisis: Some answers. Administrative Science Quarterly 26(1): 58-65. 